\title{
To Each According to their Needs: Anarchist Praxis as a Resource for Byzantine Theological Ethics
}

Emma Brown Dewhurst

Durham University

I argue that anarchist ideas for organising human communities could be a useful practical resource for Christian ethics. I demonstrate this firstly by introducing the main theological ideas underlying Maximus the Confessor's ethics, a theologian respected and important in a number of Christian denominations. I compare practical similarities in the way in which 'love' and 'well-being' are interpreted as the telos of Maximus and Peter Kropotkin's ethics respectively. I further highlight these similarities by demonstrating them in action when it comes attitudes towards property. I consequently suggest that there are enough similarities in practical aims, for Kropotkin's ideas for human organising to be useful to Christian ethicists.

\section{Introduction}

There has always been a radical message in Christianity that undermines the importance of worldly power and wealth. ${ }^{\mathrm{I}}$ Reception of this message has varied hugely across the history and geography of the church, but it has by no means been the case that the full extent of its call for egalitarianism, love, inclusivity, and communal distribution of wealth has always remained a sidelined voice in the church. In this chapter, I explore the theology of one

\footnotetext{
${ }^{1}$ E.g. Matt 5:I-I 2; Matt I9:I6-24; Matt 25:34-46; Mark I 2:30-3 I; Acts 2:42-47
}

How to cite this book chapter:

Brown Dewhurst, E. 20I 8. To Each According to their Needs: Anarchist Praxis as a Resource for Byzantine Theological Ethics. In: Christoyannopoulos, A. and Adams, M. S. (eds.) Essays in Anarchism and Religion: Volume II. Pp. 58-93. Stockholm: Stockholm University Press. DOI: https://doi.org/Io.I6993/bas.c. License: CC-BY. 
of the greatest theologians of the early Church, ${ }^{2}$ a Byzantine monk called Maximus the Confessor. Whilst in his lifetime he was a victim of persecution, his theology is now upheld as orthodox in Catholic, Eastern Orthodox, and Anglican churches. This makes him a figure of prime importance when it comes to highlighting the political and ethical outworking of an interdenominational theology for the Christian tradition.

In this chapter I present some of the foundational ideas in Maximus' theology, looking at the philosophy and metaphysics that he draws out of scripture, and demonstrate why this results in what, by today's standards, we would consider a radical ethics. I suggest that a useful way to try and formalise an ethical response to Maximus' theology would be to draw on anarchist literature, especially the ideas of Peter Kropotkin. Whilst it is clear that Kropotkin does not share the same metaphysical commitments as Maximus (or any Christian theologian), the philosophical ideas grounding Kropotkin's ethical response, have enough similarity that a Christian can (and I argue, should) look to practical anarchist principles like Kropotkin's as a possible means of living out their Christian ethics. If there is agreement between Christians that Maximus is an important theologian for us today, and that his thought has the full radical implications I demonstrate, then it should also follow that at the very least, Kropotkin's ideas for anarchist living ought to be considered as a mode of living worth pursuing.

This chapter has three parts to it. In the first, I give a short overview defining terminology and introducing the lives and contexts of Maximus and Kropotkin. In the second section I lay out the key theological ideas important for understanding Maximus' ethics. In the third section, I justify a similarity that I believe exists between Kropotkin and Maximus in their understanding of human well-being and how we ought to act. As a result of this similarity, I then conclude that Kropotkin's practical suggestions for how to live in a stateless society ought to be considered as a vital direction in which practical Christian ethics might be taken.

2 cf. Louth, Maximus the Confessor. (London: Routledge, I996), i. 


\section{Who is Maximus and What is Anarchism?}

Maximus the Confessor was born in about $580 \mathrm{AD}$ and died in $662 \mathrm{AD}$. He lived under the rule of the Byzantine Empire, the power ruling most of the Mediterranean and North Africa between 330-I 204AD. Maximus, like all theologians who lived prior to I054AD, lived before the East-West Schism in the church, making his work important within many Christian traditions. In academic circles, due to poor transmission of early Greek works to Western Europe during the medieval period and a variety of other factors, Byzantine theologians like Maximus have had relatively little attention. In the last hundred years, ${ }^{3}$ and especially the last fifty years, this has changed, and the field of Maximus studies is now a rapidly growing area. This attention has inevitably also given rise to an interest in the ethical outworking of Maximus thought, i.e. how we should live as a result of this theology. ${ }^{4}$ I mention below a few of the directions in which Maximian ethical scholarship

3 H. Von Balthasar, Cosmic Liturgy: The Universe According to Maximus the Confessor. Daley, B. (trans.) (San Francisco: Ignatius Press, I 988 (first ed. I946)), 23.

4 E.g. R. Bordeianu, 'Maximus and Ecology: The Relevance of Maximus the Confessor's Theology of Creation for the Present Ecological Crisis'. The Downside Review I27 (2009): I03-I26; D. Munteanu, 'Cosmic Liturgy: The Theological Dignity of Creation as a Basis of an Orthodox Ecotheology'. International Journal of Public Theology. 4, 3 (2010): 332-44.; E. Theokritoff, Living in God's Creation: Orthodox Perspectives on Ecology. (New York: St Vladimir's Seminary Press, 2009), 50-90; C. Brenna, 'Orthodox Cosmology and Modern Rights Theories'. NY, 20-22.09.20I2 (Conference paper delivered to the OTSA 2012 Annual Meeting, available on request). T. Tollefsen, The Christocentric Cosmology of St Maximus the Confessor. (Oxford: Oxford University Press, 2008), 225-30; T. Grdzelidze, 'Creation and Ecology: How Does the Orthodox Church Respond to Ecological Problems?' The Ecumenical Review. 54, 3 (2002): 2II-2I8; G. Popa, 'Theology and Ecology: Hermeneutical Insights for Christian Eco-Theology'. Journal for Interdisciplinary Research on Religion and Science. 2 (2008): 97-I 28; E. Zelensky, 'Nature as Living Icon: Ecological Ethos of Eastern Orthodoxy'. Religions: Vol. Environment, II (2012): I67-I79; J. Chryssavgis \& B. Foltz (eds.) Toward an Ecology of Transfiguration: Orthodox Christian Perspectives on Environment, Nature and Creation., Fordham: Fordham University Press, 20I3. 
is being taken. First, however, it is worth saying a bit about who Maximus was.

Maximus grew up either in Constantinople with ties to the civil service and the imperial court, or, depending on what sources we use, in Palestine to a relatively poor family where he had strong ties to the Palestinian monastic movement. 5 At some point, possibly around $626,{ }^{6}$ he abandoned all this and went off to become a monk in a monastery in North Africa. He was heavily influenced by a famous theologian and monk, Sophronius, whose lead Maximus would eventually follow in taking a stand in Empire-wide theological controversies. Maximus appears to have remained a monk his whole life, never being made a priest or bishop. Despite this, lay, monastic, and clerical figures from all over the empire wrote letters to him asking for his philosophical, theological, and spiritual advice on various matters. In Maximus' later life he famously wrote on the two wills of Christ, taking a theological stand during a time when political unity rather than theological orthodoxy was foremost on the imperial agenda. ${ }^{7} \mathrm{He}$ was tried for heresy and treason and eventually his right hand and tongue were cut off (these being the tools by which he spread his heresy), and he was exiled to what is now modern day Georgia, where he died later that year on $13{ }^{\text {th }}$ August $662 .{ }^{8}$ His theology on the two wills later

5 Andrew Louth argues that Maximus' familiarity with court and imperial proceedings along with his extensive education suggest that it is more likely that Maximus was born and raised in Constantinople (Louth, Maximus, 5). Along with Brock's earlier observation that Palestine would place Maximus close to his friend Sophronius, (see Louth, Maximus, 6-7), Pauline Allen argues that Maximus' theology retains a distinctly Palestinian ascetic flavour such as his response to Origenism and awareness of Neoplatonism that would be made sense of if Maximus was Palestinian born. cf. P. Allen, "The Life and Times of Maximus the Confessor", The Oxford Handbook of Maximus the Confessor. P. Allen \& B. Neil (eds.), (Oxford: Oxford University Press, 20I5), 9-I4. The controversy over Maximus' early life comes from two competing biographies of his life - an earlier Syriac one that hates him and a later Greek life that extols him.

${ }^{6}$ All dates from the tentative timeline reconstructed by Allen, "Life and Times", I4.

7 For further background see Louth, Maximus, 7-16.

${ }^{8}$ His first trial was in 655 after which he was exiled to Bizya/Thrace. His second trial was in 662 after which he was exiled to Lazica/Georgia. Cf. 
became the groundwork for the sixth Ecumenical Council and he is now venerated as a saint in the Eastern Orthodox, Roman Catholic, Anglican and Lutheran traditions.

In current theological ethics, Maximus' theology has become particularly important for environmental ethics. His work provides a strong theological grounding for the integrity of all creatures (including the earth itself, and plants and minerals). Radu Bordeianu, for example, has explored the ecological implications of Maximus' work for the current environmental crises. ${ }^{9}$ This includes considering the validity of claims pointing toward Christian theology as partially responsible for attitudes condoning environmental destruction. Whilst the accusation has some validity, Bordeianu writes that a more responsible theology has been in our grasp for centuries with thinkers such as Maximus the Confessor. ${ }^{\text {IO }}$ Another important contribution to scholarship on Maximus and ethics is a recent collection of essays that suggests how Byzantine theology, and in particular the work of Maximus the Confessor, may be a useful resource for contemporary ethics. ${ }^{\text {II }}$ In one paper in this collection, Andrew Louth admits that the world has changed a lot since the time of Maximus: the universe is not so small and young as it was thought to be, and the human and even the Earth are much more insignificant than the Byzantine mind could ever conceive. ${ }^{\mathrm{I2}}$ Despite this, Maximus' theology offers us a sense of 'the coherence of all things', ${ }^{\mathrm{I} 3}$ and an awareness of interrelation between the particular and the whole. It makes sense of how a creature might be minuscule within an enormous cosmos, and yet still have purpose and responsibility because of the choices we can make and our ability to contemplate everything

Allen, "Life and Times", I4-I 5; Louth, Maximus, I6-I8; G. Berthold, Maximus Confessor: Selected Writings. (London: SPCK, I985), 3I, note 32.

9 Bordeianu, 'Maximus'.

to Bordeianu, 'Maximus', Io3.

I See section 'I. "Knowledge United to God": Environment, Nature and Creation in Patristic Thought' in Chryssavgis \& Foltz (eds.), Toward. 9-7I.

12 A. Louth, 'Man and Cosmos in St Maximus the Confessor' in Toward. Chryssavgis \& Foltz (eds.), 68-9.

I3 Louth, 'Man and Cosmos', 70. 
around us. ${ }^{\text {I4 }}$ This description of the universe need not be at odds with our biological comprehension or scientific explanations and may rather enhance our understanding of the fragility of relationships within our environment. ${ }^{15}$ Louth posits that Maximus' vision offers a means of combining a holistic understanding of the universe with a rich sense of the place of reason. The tools of scientific theory and mathematical expression are tools that only make sense to the human, no matter how universal they appear to be. ${ }^{16}$ In this way, the search of the human for wisdom concerning its surroundings is entirely compatible with the Byzantine world view. In Maximus' thought, every human is logikos, rational, with the capacity to choose. ${ }^{17}$ This rationality is one of the greatest gifts to humankind, who as a result may choose to coexist and make peace with one another and the natural world, or, as we will see, cause devastation in its misuse of choice. ${ }^{18}$ Louth's contribution is particularly important as a contemporary source that recognises that a huge shift has taken place in our perception of the universe as a result of our scientific advances. He rightly points out that we need to justify why we are looking back to a cosmological theology prior to these scientific advancements for advice on how to live in the world today. Louth's explanation leads us to affirm that spiritual wisdom that asks us to live well with other creatures and one another is not usurped by scientific enquires but is a necessary part of what it means to be human. The utility of Byzantine thought for the Christian is that this inquiry is not seen as apart from spiritual concerns, but contextualised within a wider inquiry into who we are and how we ought to live.

Having given an overview of Maximus and his place in contemporary scholarship, I wish to define my use of the term 'anarchist', and briefly justify my choice to look at Kropotkin in this chapter. Following Peter Marshall's definition, I loosely take anarchists to be those who "reject the legitimacy of external government and of the State, and condemn imposed political

\footnotetext{
${ }^{\text {I4 }}$ Louth, 'Man and Cosmos', 68-70.

I5 Louth, 'Man and Cosmos', 70-I.

I6 Louth, 'Man and Cosmos', 70-I.

${ }_{17}$ Louth, 'Man and Cosmos', 63-4.

${ }^{18}$ Louth, 'Man and Cosmos', 68.
} 
authority, hierarchy and domination. They seek to establish the condition of anarchy, that is to say, a decentralized and self-regulating society consisting of a federation of voluntary associations of free and equal individuals", so as "to create a free society which allows all human beings to realize their full potential". ${ }^{19}$ It is difficult to make generalisations about anarchist thought, given its condemnation of set political ideologies, however, one thinker whose ideas continue to remain important in communal anarchist thought is Peter Kropotkin (I842-I92I). Kropotkin's writings are particularly valuable for the way that they intertwine philosophical critique of the status quo, anecdotal and statistical evidence of differing economic systems, biological evidence to counter the political primacy of a social survival-of-the-fittest idea, and pragmatic ideas for both long and short-term changes that can be made to society.

In Anarchy in Action, Colin Ward goes so far as to call his own book "an extended, updating footnote to Kropotkin's Mutual Aid.". ${ }^{\circ}$ Ward believes Kropotkin's continuing relevance is abundantly apparent and that, for example, "Anyone who wants to understand the real nature of the crisis of the British economy in the I980s would gain more enlightenment from Kropotkin's analysis from the 1890 s than from the current spokesmen of any the political parties." ${ }^{21}$ Ward identifies a severe paucity in the imagination of the left, which has largely abandoned "those aspirations for the liberation of work". ${ }^{22}$ Consequently, he suggests that Kropotkin's "decentralist and anarchist vision" may yet hold much for us, and he claims it is certainly much less an "absurd" idea than a socialist faith in the humanisation of work through the conquest of the state power by the proletariat. ${ }^{23}$ I have quoted Ward writing of Kropotkin's relevance in I973, 1974 and 1998, but in the wake of the 2008 economic crash,

19 P. Marshall, Demanding the Impossible: A History of Anarchism. (London: Harper Perennial, I992), 3.

20 C. Ward, Anarchy in Action. (London: Freedom Press, ( ( ${ }^{\text {st }}$ pub I973, this ed. 2008)), ro.

2I Ward, Anarchy, Iо.

${ }_{22}$ Ward, 'Introduction' in P. Kropotkin, Fields, Factories and Workshops Tomorrow. (London: Freedom Press, I998 ( $\mathrm{I}^{\text {st }}$ ed. I 898)), I3.

23 Ward, 'Introduction' in Kropotkin, Fields, I 3. 
I think Kropotkin's ideas are more important than they ever have been before. Following the systemic failures of state socialism and capitalism, Kropotkin's ideas look ever more prophetic and attractive. Most importantly for this chapter, the ethical commitments underlying Kropotkin's practical writings share much with the key features I identify in Maximus' ethics, making his work a good potential resource for Christian praxis.

\section{The Cosmic Theology of Maximus the Confessor}

I outline here three areas that are important for understanding how Maximus believes humans should live. I explain how Maximus believes the cosmos is held together (2a). This allows us to glimpse the way he believes all nature ${ }^{24}$ and creatures are linked to one another and to God, since for Maximus the universe is not merely a physical place, but also possesses a spiritual dimension. I then (2b) discuss the specific importance Maximus places on the human and the responsibilities that go with this importance. Lastly I look at what, practically speaking, Maximus believes human activity - ethics - should consist of (2c).

\section{2a. Union and Distinction}

Maximus' theology can be understood in terms of 'union and distinction'. ${ }^{25} \mathrm{He}$ believes that all things will be gathered to union with one another in God, but will still retain their unique, distinct identity when they are united. ${ }^{26}$ This means that his theology is a delicate balance between a desire for harmony and unity of all things, and a dedication to the freedom and personal expression of every creature. Maximus writes that we deepen our knowledge of God by understanding and discovering meaning within one

${ }_{24}$ Used here as a lay term for creation, especially non-human creation, rather than in the theological sense of physis.

25 Proposed as a systematic way of reading Maximus' theology by M. Törönen, Union and Distinction in the Thought of St Maximus the Confessor. (Oxford: Oxford University Press, 2007).

${ }^{26}$ Maximus, Myst. TCr. Ch.I. 
another and the natural world. ${ }^{27}$ As this occurs we begin to overcome the divisions and confusions that keep creatures at enmity with one another. ${ }^{28}$ Drawing on Ephesians I:Io, Colossians I:I6 and similar passages, Maximus explores the way in which the cosmos is recapitulated and made whole in Christ. ${ }^{29}$ God intends all of creation to be drawn towards God and united in love, and God works towards this end continually. ${ }^{3 \circ}$ Maximus uses the example of travelling from the edge of a wheel down the spokes to the centre - in this example, creatures that move towards God (the centre) also move towards each other, coming closer spiritually and overcoming odds with each other as they are motivated by love. ${ }^{3}$ Thus, unity, perfection and participation in God shall be reached when "there shall be no intentional divergence between universals and particulars". ${ }^{2}$ For Maximus, the providential end for creatures is to be gathered to God and all divisions overcome, while the identity of each creature is never at risk of being abolished. ${ }^{33}$ Particular creatures continue to exist, but the difference between one creature and the next is no longer a source of conflict, and is instead a cause for celebration. ${ }^{34}$ As Melchisedec Törönen explains, number is thus difference without being division, ${ }^{35}$ so that, just like "When we speak of a two-coloured or five-coloured stone (or of any multi-coloured one) we do not divide the one stone into two or five stones". ${ }^{36}$ Although we can count many things in one, it does not make it many - and although something is one, it does not mean we cannot pick out the unique colours within it.

${ }_{27}$ Maximus, Amb. 2 I I 248C-D in On Difficulties in the Church Fathers: The Ambiguua Vol I. Constas, N. (ed.) (London: Harvard University Press, 20I4), 434.

${ }_{28}$ Maximus, Amb. 4I PG9 I I3 I3B in On Difficulties in the Church Fathers: The Ambiguua Vol II. Constas, N. (ed.) (London: Harvard University Press, 20I4), I I 8 .

29 Maximus, Amb. 4I PG9I I308D in On Difficulties II, Io6-8.

$3 \circ$ Maximus, Ad Thal. 2, $\mathrm{CCSG}_{7}: 5 \mathrm{I}$.

${ }^{\text {I }}$ Maximus, $A m b$ 7. 108 I B-C in On Difficulties I, Io०.

${ }^{2}$ Maximus, Ad Th. 2, 7:5I (Blowers (trans.), On the Cosmic Mystery of Jesus Christ. (New York: St Vladimir's Seminary Press, 2003), I00).

33 Maximus, Amb. Io. I I89A in On Difficulties I, 3 Iо.

${ }_{34}$ Cf. Maximus, Myst. TCr. ChI.

35 Törönen, Union and Distinction, 42.

${ }^{36}$ Maximus, Epp. I2 PG9I 476A-C (Törönen (trans.) Union, 42). 
Maximus' vision for the world is one where there is both perfect community and yet distinct personal relation that comes about through Christ. He writes:

For the wisdom and sagacity of God the Father is the Lord Jesus Christ, who holds together the universals of beings by the power of wisdom, and embraces their complementary parts by the sagacity of understanding, since by nature he is the fashioner and provider of all, and through himself draws into one what is divided, and abolishes war between beings, and binds everything into peaceful friendship and undivided harmony, both what is in heaven and what is on earth, as the divine Apostle says. ${ }^{37}$

Vladimir Cvetković notes that in advocating this kind of union, Maximus' cosmology “abolishes all the divisions that exist in the humankind, not only those established by gender differentiations, but also those based on national, ethnic, political, cultural, educational and any other platform"..$^{38}$ In proposing that we are guided in the direction of union, and in the overcoming of divisions between creatures, Maximus implies that there is no place for the judgement, exclusion or abuse of another being on the basis of its difference. ${ }^{39}$ Difference is not to be a dividing factor, but a celebration of intended diversity that brings creation closer together as it exhibits love and moves closer to its intended end in God. The conclusion Maximus leaves us with is that there is no place within the cosmos for ideological, political, racial or any other kind of hatred. What we hate, we divide from us, and in doing so also separate ourselves from God..$^{\circ}$ What we love, by contrast is brought to God, who is love. ${ }^{4 \mathrm{I}}$

37 Maximus, Amb. 4I PG9 I I3 I3B in On Difficulties II, I I 8 (Louth (trans.), Maximus, I62).

${ }^{38}$ V. Cvetković, 'Maximus the Confessor's Geometrical Analogies applied to the Relationship between Christ and Creation' in P. Pavlov, et al.(eds.), Orthodox Theology and the Sciences. (Columbia: Newrome Press, 2013), 277.

39 Cf. Maximus, Amb. 4I PG9 I I $305 \mathrm{C}$ in On Difficulties II, I04; Maximus, Myst. TCr. Ch.I; cf Col. 3:I I-I 5 .

40 "The one who sees a trace of hatred in his own heart through any fault at all toward any man whoever he may be makes himself completely foreign to the love of God, because love for God in no way admits hatred for man." Maximus, De char. PG9o 963 C I.I 5 (G. Berthold (trans.), Maximus, 37].

${ }_{41}$ Maximus, De char. PG9o 963B I.I3. 
The existence we lead and the communities we choose to be a part of must therefore reject persecution and social division based on the differences we see in one another. An ethical exploration of this cosmology might lead one, for example, to question the necessity and utility of societal and legal divisions and borders that discriminate on bases such as culture, ethnicity and wealth. Anti-discrimination ideas are often upheld in Christian ethics by an appeal to human rights laws, ${ }^{42}$ but the ethical possibilities that could be derived from Maximus might go further than these to challenge more basic artificial boundaries such as those of nations and territorial borders. The discrimination involved in the maintenance of borders is particularly well illustrated in the manifesto of the decentralised grassroots organisation 'No Borders'. They point out that the maintenance of a border elevates movement of people into a commodity purchasable only by those with the economic wealth or political power to do so. The system of deportation and border control targets and criminalise those who are poor. In this way, 'No Borders' write, “Modern states try to turn movement into a right that is granted or denied according to economic and political power". ${ }^{43}$

Maximus' understanding of union and distinction brings a further dimension to the ethical outworking of 'love your neighbour' (Mark I2:I3; Matt. 22:39). It is clear that, for Maximus, diversity found in different communities and cultures is a cause for celebration, and is one of the ways in which creation is brought together. We are many in our diversities and yet one in celebration of this and in our day-to-day relations of love. This means that a particular culture can be celebrated, but when that identity is exclusive, insular and inspires hatred for what is different instead of love in multiplicity, it becomes a source of division that breaks apart the unity of the cosmos. In my mind, it would be hypocritical to consider Maximus' cosmic theology to be a call for equality between

${ }^{42}$ See for example, A. Papanikolaou, The Mystical as Political: Democracy and Non-Radical Orthodoxy. (Indiana: University of Notre Dame Press, 2OI2), I 28.

43 No Borders, 'A No Borders Manifesto': http://noborders.org.uk/node/47 (Accessed 20.03.I4). 
the sexes ${ }^{44}$ without also considering it to be a condemnation of refusing asylum seekers or migrant workers entry into a country. Maximus' balance between union and distinction is one that calls for communal care but also personal freedom through Christ-like love. ${ }^{45}$ This love is always about loving every particular person, especially the persecuted, powerless, and marginalised. Divisions within our society that breed hatred, alienation, or otherwise limit the extent to which one may love, have no place within the cosmic scope of Maximus' theology.

\section{2b. The Human as Microcosm}

Within Maximus' cosmological thought, humans play an important role. With this importance, however, comes a responsibility. Humans possesses reason and free will. For Maximus, this means that humans are uniquely placed to be the voice of voiceless creation, and have the potential to express all creation with that voice and so commend the cosmos as one to God. ${ }^{46}$ Following, amongst others, Gregory of Nyssa, ${ }^{47}$ Maximus understands each human to contain all the cosmos within them - to be micro-cosmos. ${ }^{48}$ A human partakes of and is able to contemplate both visible and invisible things, and is thus like a "laboratory in which everything is concentrated and in itself naturally mediates between the extremities of

${ }_{44}$ Male and female are discussed as distinctions in humans that are overcome in Christ. Maximus believes that prior to the Fall humans were without sex or gender (based on Gal. 3:28 and his reading of Genesis) and that procreation probably happened in a different way: (Maximus, Amb. 4I PG9 I 305 C \& I309A-I3I2A in On Difficulties Vol II, I04, I IO-II4). See also S. Mitralexis, 'Rethinking the Problem of Sexual Difference in Ambiguum 4I' Analogia: The Pemptousia Journal for Theological Studies 2:I (2017), I39-I 44.

${ }_{45}$ Maximus, Amb. 4 I PG9 I I308B-C in On Difficulties II, I06-8.

${ }_{46}$ Maximus, Amb. 4I PG9 I I 305 B in On Difficulties II, I04].

${ }_{47}$ "It has been said by wise men that man is a little world in himself and contains all the elements which go to complete the universe." Gregory of Nyssa, 'On the Soul and the Resurrection' in Gregory of Nyssa: Dogmatic Treatises W. Moore \& H.A. Wilson (trans.) (New York: Christian Literature Publishing Co. I892), 682.

${ }^{48}$ Maximus, Myst. TCr. Ch.7. 
each division". ${ }^{49}$ Maximus believes that the human person's unique possession of both rationality and sensibility ${ }^{50}$ means that they are capable of mediating the differences within the created order and bringing it into harmony and coexistence. ${ }^{5}$

Drawing heavily on Paul's letters, in his Ambiguum 4I, Maximus illustrates that, when humanity chose to turn away from God, it was the ability to mediate between God and the rest of creation that was lost to humanity. ${ }^{52}$ When Christ became incarnate as both God and human, he united creation with God. ${ }^{53}$ Through his death and resurrection Christ makes relationships between creation and God possible again. ${ }^{54}$ It was humanity that caused the fractures in the relationships between heaven and earth, and within creation itself. As such it is as a human that God comes to restore mediation and harmony. ${ }^{55}$ Humans, then, can choose to partake in this restored ability to mediate through Christ. We do so by freely choosing to try and coexist in love, bringing together all of creation in unity. ${ }^{56}$ When writing on the place of mediation in Maximus' cosmology and its relevance for today, Louth notes:

St Maximus's divisions of nature may seem to us quaint, but his idea that within the manifold that is the created order there are divisions that can either, when transcended, express the richness and beauty of the created order or, alternatively, cause gulfs of incomprehension, darkness, and pain seems to me an insight of continuing relevance. ${ }^{57}$

Louth's exposition, which specifically refers to the theology in Maximus' Ambiguum 4I, makes the point that we do not have to sign-up to the specific philosophical and metaphysical structures

\footnotetext{
49 Maximus, Amb. 4I PG9 I I305A-B in On Difficulties II, I02-4.

50 Maximus, Amb. 4I PG9I I305D-I308A in On Difficulties II, I06.

${ }^{1}$ Maximus, Amb. 4I PG9 I $1305 \mathrm{~B}-\mathrm{C}$ in On Difficulties II, I04.

${ }^{2}$ Maximus, Amb. 4I PG9 I I308C-I3 I2B in On Difficulties II, Io8-I I4.

53 Maximus' theology is heavily reliant on the 'logic' of the Council of Chalcedon (45I) which affirmed Christ as being one person in two distinct natures of human and divine.

54 Maximus, Amb. 4I PG9 I I308C in On Difficulties II, Io8.

55 Maximus, Amb. 4I PG9I I308D in On Difficulties II, I08-I Io.

${ }_{56}$ Maximus, Amb. 4I PG9 I I308B-C in On Difficulties II, Io6-1o8.

57 Maximus, Amb. 4I PG9I I308B-C in On Difficulties II, I06-I08.
} 
of a Byzantine worldview in order to see value in the recognition that human choices have got the world into the mess it is in today. Whether we are discussing environmental destruction, extreme inequalities in wealth, or social, political, economic or cultural discrimination, exploitation and persecution, the means to deepening these rifts or alleviating one another from suffering have the potential to come from uniquely human decisions and choices. This is one of the many reasons that, in the Byzantine ascetic tradition, the question of what humans should do begins with a reflection on one's own actions and the way we treat others and the world around us. ${ }^{8}$ This, in turn, is never separate in the Byzantine mind from the perpetual activity of Christ and the Spirit in our lives and a reciprocal relationship rooted in grace and free will that occurs between God and the human. ${ }^{59}$

For Maximus, the ability to choose and deliberate and possess rationality (logos), is a natural ability of humanity. With possession of this power however comes a responsibility to the rest of creation. The abuse of rationality and the divisions that form within our societies (between fellow humans and between the human and the rest of the natural world) have devastating effects. The gifts humanity has been given of grace, capacity to love and capacity for wisdom, are ones that come with a terrible price for all creation when humanity falls short of its natural ability and potential. This foresight in the effect of human activity within its own societies and upon the environment is just one of the ways in which Maximus' thought might challenge the Christian conception of who we are, what might be possible, and what the failures to love difference imply. This cosmology proposes that, because we can love, we have an obligation to love. To put our rationality purely to self-service has demonstrably destructive consequences for everything touched by that choice. This is a cosmology that

${ }^{5}$ See for example, K. Ware 'Through Creation to the Creator' \& A. Keselopoulos, 'The Prophetic Charisma in Pastoral Theology: Asceticism, Fasting, and the Ecological Crisis' in Toward an Ecology of Transfiguration: Orthodox Christian Perspectives on Environment, Nature and Creation. J. Chryssavgis, \& B. Foltz, (eds.), (Fordham: Fordham University Press, 2013).

59 Maximus, Or. Dom. PG9o 877A. 
speaks of the beauty of the whole, but also of its fragility as a cosmos built on interrelation.

\section{2c. The Ascetic Practice of Love}

Lastly then, let us look at what Maximus believes this cosmology will translate into in terms of human action. We have seen that Maximus believes that the human is tasked with uniting the cosmos through their choice to love, but what does this mean and what does this look like? What does Maximus mean by love? How does one seek God's meaning in creation, move towards God and mediate between creatures? Maximus answers that these hopes are made possible in Christ and by following him in faith and in the practice of love. ${ }^{60}$ To practise love is to follow the example of the life and death of Christ. ${ }^{61}$ By grace we have faith, rational choice, the ability to mediate, and restoration in Christ, but we ourselves must have the voluntary inclination to eradicate the troubles ('passions') that run counter to human nature. ${ }^{62}$ We were made naturally good, but it is through the fall and our continuing choice to sin (to turn away from God, who is love) that human nature is occluded by passions that separate us from God.

Behind Byzantine cosmology, and also at its heart, is the ascetic way of life. ${ }^{63}$ Rooted in the Gospel and then developed by early Christian desert monks, ascetic thinking occasionally took the form of 'centuries'. ${ }^{64}$ These were a set of one-hundred aphorisms upon which one might meditate that would aid one in the struggle to live a practical, Christian, spiritual life. Through simple means of self-discipline and a life of love and humble giving, one might grow in wisdom, and begin to tread along the path in the Byzantine cosmic vision that brings all creation closer to harmony, unity, perfection, and ultimately to God. In his Centuries

\footnotetext{
${ }^{60}$ Maximus, De char. PG9o 975 C I.27.

${ }_{61}$ On cultivating the mind of Christ: Maximus, Th.oec. PG9o I I63 B II.83; on discerning the logoi through a pure mind: De char. PG90 $98 \mathrm{IC}$.

${ }^{62}$ Maximus, Th.oec. PG9o I I 27 B II.6.

${ }_{3}$ Louth, Maximus, 44.

64 P. Sherwood, The Ascetic Life and The Four Centuries on Charity. (New York: The Newman Press, I955), I02; Evagrios of Pontos is credited with inventing the 'century' format of ascetic literature.
} 
on Love, Maximus writes four sets of a hundred statements that guide the reader in their search for wisdom, their internal battle with passions that plague them, and their struggle to live a life of genuine compassion and love for fellow creatures. For example, he writes:

If you harbour resentment against anybody, pray for him and you will prevent the passion from being aroused; for by means of prayer you will separate your grief from the thought of the wrong he has done you. When you have become loving and compassionate towards him, you will wipe the passion completely from your soul. If somebody regards you with resentment, be pleasant to him, be humble and agreeable in his company, and you will deliver him from his passion. ${ }^{65}$

Following the words of St Paul, Maximus also urges the ascetic to "Rejoice with those who rejoice and weep with those who weep". ${ }^{66}$ This is the way in which one may have the 'mind of Christ'. ${ }^{67}$ By preparing one's heart and mind this way, Maximus believes that one can begin to perceive real meaning in the world about us. As the intricacies of the created world become visible to us, so will we come to know God through all creation about us. ${ }^{68}$ Knowledge, harmony and holiness are pursued through freely choosing to practice love. Love takes the form of learning to be merciful, patient, and kind even when someone frustrates or hurts us; it is a means to helping others see faults within themselves that they can learn from, rather than reinforcing cycles of alienation and hatred. ${ }^{69}$ This, I think, might be a suitable way of summing up ascetic practice according to St Maximus. The broader hope is union and reforging the relationship between the creator and all creation, but the minutiae takes place in the simple life of the human person, who, in possessing rationality, may choose to live in such a way that brings peace to those around them.

${ }_{65}$ Maximus, De char. PG9o I043D III.90 (Louth (trans.), Maximus, 39).

${ }_{66}$ Maximus, De char. PG9o I043D-I045A III.9I; Romans I2:I 5.

${ }_{67}$ Maximus, Th.oec. PG9o I $163 \mathrm{~B} \mathrm{II.83.}$

${ }_{68}$ Maximus, Th.oec. PG90 I I6ICD II.79; I I6ID-I I64A 80.

69 Contemplation of the logoi in Maximus' writings is discussed in relation to contemporary ethics in D. Bradshaw, 'The Logoi of Beings in Greek Patristic Thought' in Toward, 9-22; Louth, 'Man and Cosmos', 59-7I. 
At its simplest, this cosmology is an exposition of the need to practice love in the human life. Love, as defined by Maximus with reference to Paul, is Christ-like love. It is the challenge that requires the humility of the self and giving to the other. As Maximus writes, "The one who loves God surely loves his neighbour as well. Such a person cannot hold on to money but rather gives it out in God's fashion to each one who has need". ${ }^{\circ}$ The ethical implications of such a love are already being teased out by Maximus here. Love equates to seeing the suffering of others as the suffering of Christ, and to giving to others as Christ has given to us. This naturally means that money and possessions go to those who need them. Accumulation of property and wealth are thus deeply problematic and sinful acts. ${ }^{7 \mathrm{I}}$ Maximus has begun talking of the economic relationships that result from this love, but we can also think about the requirements of such love on our political relations. In an ethics where personal care for the other is paramount, the structures of a system that maximises personal profit at the expense of others becomes unacceptable and incompatible with an entire Christian worldview. David Harvey gives us a concise overview of what he believes a neoliberal agenda to be, writing that it "proposes that human well-being can best be advanced by liberating individual entrepreneurial freedoms and skills within an institutional framework characterised by strong private property rights, free markets, and free trade"..$^{72}$ Dedication to preserving an individual's right to wealth and property brings about an attitude that cannot hope to comprehend love as the basis of economic relation. The telos of love $\mathrm{e}^{73}$ in Maximus' ethics

${ }^{70}$ Maximus, De char. PG90 965B I.23 (Berthold (trans.), Maximus, 37).

${ }^{71}$ i.e. Acts that separate us from God, because they are unloving. The problem of property is discussed further in $3 \mathrm{~b}$. Positions on Property.

72 D. Harvey, A Brief History of Neoliberalism. (Oxford: Oxford University Press), 2.

73 The telos of the ethical life for Maximus is theosis, perfect union with God, in which we still remain distinct persons. Since God is love, and we have a very practical demonstration of this love in Christ's life and death, we do not lose anything by simply calling the telos of Maximus' ethics 'love'. For a full discussion of the telos of Maximus' ethics, see 'Chapter 2: A Telos of Theosis' in my doctoral thesis Revolution in the Microcosm: Love and Virtue in the Cosmological Ethics of St Maximus the Confessor. 
brings it into direct confrontation with ideologies grounded in capital accumulation and protection of private property. If we took giving to those in need as the basis of our economic and political theories and relations, we would have to radically restructure the economic systems and policies of any current capitalist state. If in any of our activities, whether on an individual or collective basis, we perpetuate the economic, political and social oppression of someone elsewhere on the globe, we have by definition a lifestyle that is deeply problematic for anyone who considers love to be integral above all else. Maximus' cosmic and ascetic theology points Christian ethics in a direction that seriously calls into question the basic premises of any society that runs counter to a requirement of love.

\section{Ethical Commitments in Maximus and Kropotkin}

Next I turn to look at Kropotkin's ideas and some of the possible compatibilities these might have with Maximus' thought. In particular I examine the way that Kropotkin's practical ideas for society may be useful resources when extending Maximus the Confessor's ethics to the present day. I first consider the philosophical and anthropological underpinnings of Kropotkin's anarchist theory. For there to be grounds for a similar ethical praxis (means), there must be a semblance of a shared goal (end/telos). I have already intimated that a shared metaphysical telos will not be apparent in Maximus and Kropotkin's ethics, but I suggest here, that the vision for human life on earth is underpinned in both Maximus and Kropotkin by the same kind of philosophical principles. I examine the concepts of mutual aid and well-being in Kropotkin's thought and compare this to Maximus' understanding of love - arguing that the character of these concepts is similar enough to be valuable grounds for ethical praxis. Following this, I discuss their positions on private property as a way into considering the commonalities in their bases for human economic relationships. Lastly, I look at some of Kropotkin's practical

(PhD diss., Durham University, 20I8) (Available online: http://etheses. dur.ac.uk/I 2376/I/Brown_Dewhurst-_Revolution_in_the_Microcosm. pdf?DDD $32+), 63-92$. 
suggestions for an anarchist society and indicate how these might be useful developments for those who use Maximus' theology as an ethical basis today.

\section{3a. Mutual Aid and Well-Being}

In his autobiography, Kropotkin describes how from a young age he was deeply distressed by the inequality, injustice and oppression inherent in serfdom, and the expectations in social interaction this system enforced. ${ }^{74}$ As the son of a wealthy landowner, he tells of the horror he felt at the way that serfs were treated in his father's household. After one incident when he was about ten years old, Kropotkin wrote of the following encounter:

Tears suffocate me, and immediately after dinner is over I run out, catch Makár in a dark passage, and try to kiss his hand; but he tears it away, and says, either as a reproach or as a question,

"Let me alone; you, too, when you are grown up, will you not be just the same?"

"No, no, never!" 75

From then on in his memoirs, Kropotkin describes a continual struggle to confront the injustices he found in Russian society. Remaining at the heart of his struggle is the desire to give to those in need, to bring a measure of fairness into the lives of those about him and above all "not be just the same" as the privileged who kept others enslaved. He claimed it was no good wanting to change society simply through the idea of the 'right to work' or 'to each the whole result of his labour'. ${ }^{76}$ What had to be at the heart of desire for change in human society was hope for 'well-being for all', 77 based on a principle of 'to every [wo/]man according to [her/] his needs' ${ }^{78}$ It was in this way that common people could

\footnotetext{
74 P. Kropotkin, Memoirs of a Revolutionist. (New York: Dover Publications, I97I (I899 ( ( ${ }^{\text {st }}$ ed.))), Chapter VIII, 48-62.

75 Kropotkin, Memoirs, $5 \mathrm{I}$.

${ }^{76}$ P. Kropotkin, The Conquest of Bread. (Milton Keynes: Dodo Press, I 892), IO.

77 Kropotkin, Conquest, II.

${ }_{78}$ Kropotkin, Conquest, 24.
} 
become "the builders of a new, equitable mode of organisation of society". ${ }^{79}$

Kropotkin justifies his belief in the need for a society that seeks the well-being of all by locating a driving factor for this in an evolutionary tendency of the natural world towards co-operation. He notes that while the traditions and history of a society play an important part in the development of ethics, conscience itself "has a much deeper origin, - namely in the consciousness of equity, which physiologically develops in man as in all social animals ... ${ }^{8 \circ} \mathrm{He}$ writes that a key factor of evolution has been the social development and ability of animals to co-operate with one another in order to survive. ${ }^{8 \mathrm{I}} \mathrm{He}$ calls this the 'mutual-aid tendency', believing it to be something more base and instinctive than human feeling and sympathy. For him it is a kind of natural propensity for solidarity, "an instinct that has been slowly developed among animals and men in the course of an extremely long evolution, which has taught animals and men alike the force they can borrow from the practice of mutual aid and support, and the joys they can find in social life" ${ }^{82}$ At face value, there appear to be a number of similarities between this mutual-aid tendency toward co-operation and Maximus' claim that to love is natural and involves voluntarily giving, sharing and caring for others. However, we have quite an explicit quotation from Kropotkin claiming that it is not enough to say that human society could be founded on 'love'. ${ }^{83}$ To address this accusation it is important to situate Kropotkin's thesis, Mutual Aid, in its context.

Mutual Aid was a vital work of its time, challenging the legitimacy of emerging social Darwinism at the end of the nineteenth century and proposing that cooperation, as well as struggle, had foundations in evolutionary science. ${ }^{84}$ Social Darwinism exacerbated the struggle of the individual in nature and derived from it a

79 Kropotkin, Memoirs, 379.

8० P. Kropotkin, Ethics: Origin and Development. (Montréal: Black Rose Books Ltd., I992 (I922 I I $^{\text {st }}$ ed.)), 338.

${ }^{81}$ P. Kropotkin, Mutual Aid: A Factor of Evolution. (Boston: Extending Horizons Books, I902), xvi.

${ }^{82}$ Kropotkin, Mutual, xiii.

$8_{3}$ See Kropotkin, Mutual, xii-xiii.

${ }^{84}$ Kropotkin, Mutual, ix-x. 
series of natural facts about the capability of the human and from there a legitimacy in the way in which human societies operated..$^{85}$ Kropotkin's Mutual Aid really set about challenging the premise that the struggle of the individual is all that can be found in nature (or in Darwin's theory, for that matter). ${ }^{86}$ However, the extent to which ethics should be informed by observing nature was not called into question. This makes sense of why, for Kropotkin, it is not enough to say that human society could be founded on 'love', though the concept for him is a nonetheless important emotion derived from this natural 'mutual-aid tendency'. ${ }^{87}$ Kropotkin still holds that scientifically proven tendencies in human nature must dictate the shape of our societies. ${ }^{88}$ Of course, this does not really explain why it could not be possible for the human, which believes itself to have developed the capability to love, to base its societies upon such a relation. Kropotkin writes, "It is not love of my neighbour - whom I often do not know at all - which induces me to seize a pail of water and to rush towards his house when I see it on fire. .." ${ }^{89}$ But need it not be? The heart of Byzantine ascetic literature is the assertion that the human can precisely cultivate an attitude of love toward any neighbour, even one previously not known. ${ }^{90}$ Since we are able to cultivate such an attitude, we have a responsibility to live in this way, Maximus believes, as we are the only creatures on earth who have sufficiently developed the rational capacity to live in such a fashion and thus enable harmony between all creatures. ${ }^{91}$

Whilst the semantics may be debated, it is clear that Maximus' depiction of love as the foundation of human relationships does not sit at odds with Kropotkin's hope for 'well-being for all'. We have in both Kropotkin and Maximus, a concept that extols the importance of particular free will and identity, whilst recognising

\footnotetext{
${ }_{5}$ Kropotkin, Mutual, ix.

${ }^{86}$ See Kropotkin, Mutual, viii-xii.

87 See Kropotkin, Mutual, xii-xiii.

88 Cf. Chomsky's doubt on the utility of this kind of thought in anarchism see, Chomsky, 'Interview with Ziga Vodovnik' in Chomsky on Anarchism. B. Pateman (ed.) (Edinburgh: AK Press, 2005), 240.

89 Kropotkin, Mutual, xiii.

${ }_{9 \circ}^{\circ}$ Maximus, De char. PG9o 964C I.I 5 .

9r Maximus, Amb. 4I PG9 I I308B-C in On Difficulties II, Io6-8.
} 
that we are also naturally social creatures who ought to care for one another's well-being and give to one another according to the needs of each. Kropotkin's scientific reasoning, although appearing to conflate normative and descriptive accounts of evolution, is certainly not a boundary to the Christian seeing utility in his ideas and practices. A key part of Byzantine cosmology is that it is not only human well-being that is sought for, but the well-being of the entirety of nature, of which humanity is a part. 'To every man according to his needs' might be a key slogan of nineteenth century Marxist and anarchist thought, but the sentiment is much older and one of the places it was cultivated as a way of life was in the practical ascesis of Christian desert monasticism: “. . . in God's fashion to each one who has need". ${ }^{22}$ To give to another person is to do the work of God, according to the Gospel and early church. ${ }^{93}$

\section{3b. Positions on Property}

In examining Maximus and Kropotkin's positions on property, we can see philosophical principles become ethical directives. Property is matter we become attached to, regardless of whether we need it, and often at the expense of another human who goes without as a result of our attachment. It is thus an ideal topic to focus on when looking at how a theoretical dedication to love or well-being ${ }^{94}$ takes on a practical ethical dimension.

The anarchist position on property is often summarised in Proudhon's famous slogan 'Property is Theft!'.95 The practicality

92 Maximus, De char. PG9o 965A I.23 (Berthold (trans.), Maximus, 37)].

93 John I $5: 13$.

94 In using these concepts side-by-side I do not mean to imply that Maximus' 'love' and Kropotkin's 'well-being' should be used interchangeably. As a result of ( 3 a), I think we have sufficient grounds to consider them similar ethical principles or ends, and thus to us to think of them as approximately equivalent in the context of inquiry into ethical praxis.

95 P. Proudhon, 'Property is Theft' in No Gods, No Masters. D. Guerin (ed.), (Edinburgh: AK Press, I998), 48-54; We can find this sentiment also expressed in early Byzantine theology. Basil of Caesarea writes "Is not the person who strips another of clothing called a thief? And those who do not clothe the naked when they have the power to do so, should they not 
of this position however seems better expressed by Kropotkin. "What we want is not the redistribution of overcoats," writes Kropotkin, but ". . . the day when the worker in the factory produces for the community and not the monopolist - that day will see the workers clothed and fed." ${ }^{96}$ More important than who owns what possession is the creation of an environment in which the human person may live without being in want. The capitalist mentality and the 'middle-class rule', as Kropotkin calls it, has a "morality drawn from account books, [and] its 'debit and credit' philosophy, its 'mine and yours' institutions" must be demolished. ${ }^{97}$ The threat of Kropotkin's anarchism is that "we will do our utmost that none shall lack aught"..$^{8}$ Thus for Kropotkin, property is a resource, necessary for keeping humans alive and ensuring human well-being. When it is seized and commandeered by one class to keep another in subjection, human well-being is obfuscated by the violent greed of those in power. Or to borrow the words of St Basil of Caesarea: ${ }^{99}$

It is as if someone were to take the first seat in the theatre, then bar everyone else from attending, so that one person alone enjoys what is offered for the benefit of all in common - this is what the rich do. They seize common goods before others have the opportunity, then claim them as their own by right of preemption. For if we all took only what was necessary to satisfy our own needs, giving the rest to those who lack, no one would be rich, no one would be poor, and no one would be in need. ${ }^{100}$

be called the same? The bread you are holding back is for the hungry, the clothes you keep put away are for the naked, the shoes that are rotting away with disuse are for those who have none, the silver buried in the earth is for the needy. You are thus guilty of injustice toward as many as you might have aided, and did not." Basil of Caesarea, 'I Will Tear Down My Barns' in On Social Justice. C.P. Schroeder (trans.) (New York: St Vladimir's Seminary Press, 2009), 69-70.

${ }_{96}$ Kropotkin, Conquest, 33.

97 Kropotkin, Conquest, I 56.

$9^{8}$ Kropotkin, Conquest, 39.

99 c. 329-379 AD, one of the Cappadocian Fathers - the great theologians of the early Church.

זo Basil of Caesarea, 'I Will Tear Down My Barns' in On Social Justice. Schroeder (trans.), 69. 
Kropotkin's position on property comes straight out of his commitment to human well-being and the presence of the mutual aid tendency. How we distribute resources, and also how we structure our relationships is informed by Kropotkin's commitment to his ethical principles. Hierarchies of power and class, and divisions into mine and yours, disrupt not just an immediate ability for those in want to access what they need, but also entrench isolation, alienation, and exploitation in human societies. For Kropotkin, rethinking these relationships makes sense sociologically and anthropologically speaking. For the Christian, to give to the other and to overcome division in human society and the natural world is draw near to God and to fulfil human potential as made possible by Christ. ${ }^{\text {Ior }}$

Following in the footsteps of the Acts of the early church, ${ }^{\text {102 }}$ desert ascetics prior to and during the Byzantine empire were proponents of communal property. I wish to draw attention to the mindset that such an understanding of property perpetuated. This is point made by Maximus, ${ }^{103}$ but I think the following story from the sayings of the Desert Fathers and Mothers illustrates it better:

There were two old men who dwelt together for many years and who never quarrelled.

Then one said to the other: "Let us pick a quarrel with each other like other men do."

"I do not know how quarrels arise," answered his companion.

So the other said to him: "Look, I will put a brick down here between us and I will say "This is mine.' Then you can say 'No it is not, it is mine.' Then we will be able to have a quarrel."

So they placed the brick between them and the first one said: "This is mine."

His companion answered him: "This is not so, for it is mine."

To this, the first one said: "If it is so and the brick is yours, then take it and go your way."

And so they were not able to have a quarrel. ${ }^{\text {ro4 }}$

\footnotetext{
тог Matt. 25:34-40.

I02 Acts 2:42-47.

${ }^{103}$ Maximus, De char. PG9o 965A I.23; 965 C I.26.

${ }^{104}$ J. Wortley (ed. \& trans.) The Anonymous Sayings of the Desert Fathers: A Select Edition and Complete English Translation. 'The Quarrel', N.352/I 7.26
} 
The politics of possession, property and coexistence are all expressed within the ascetic life that treats the act of love as a lifestyle and set of choices made in order to live like Christ. The story of these two old men reflects on what it means to be holy and to truly be at peace with another person. Not only are one's actions to be unhurtful, but one's entire attitude is to be cultivated to the point where to take when another needs becomes an utterly nonsensical and bizarre notion. Possession and property hold no value in an ethos where meaningful relation is expressed through giving. It does not matter whose brick it is, rather that it be given to the one in need and that the object not become the source of conflict between two people who might otherwise live in peace. Our economic relations, I think, are often the basis of our social relations and attitudes. To live in a society where protection of private property and free trade are paramount is to set an expectation for social relations built upon these ideas. Our perceptions of value and our interactions with others are built upon deserve, merit and right, rather than a comprehension of compassion and the needs of others.

Both Kropotkin's anarchism and Christian desert monasticism seem to share an understanding that along with the economics of giving and communal living, there must be a change in our mindsets and consequently our social relationships. Although there are many differences between the kind of communal living Kropotkin imagined and that of the monastic movements in the early church, there are certain similarities in the kinds of changes both communal ideas required of people. Both require not merely a relocation of objects but a change in the conception of how property rules our relationships, and how attachment to wealth should never come before a dedication to the well-being of another person. The categories of 'mine' and 'yours' were as common in Byzantine cities as they were in $19^{\text {th }}$ century capitalist states and allowed no space for the prioritising of people rather than the acquisition of things. ${ }^{\text {IO5 }}$ What Kropotkin's communalism and some desert monastic practices share, is a turning upside down of

${ }^{105}$ On this see Basil's sermons 'To the Rich' and 'I Will Tear Down My Barns' in Social Justice. Schroeder (trans.), 4 I-7I. 
the idea that accumulation of material possessions has to do with merit, and a positive disregard of any practices that do not focus on the integrity and well-being of the human being. ${ }^{106}$ What is really required is a change in our priorities, so that instead of our ultimate aim being an ideal of, say, the distribution of property, we instead dedicate ourselves to the well-being of all and giving to each according to their needs. ${ }^{\text {I07 }}$ Outside of some present-day monastic communities, there now seems very little emphasis on either the economic or socio-political implications of property within the Christian tradition. Whilst Christianity has its own history of communal living and property, ${ }^{\mathrm{1} 08}$ it may be that the modern anarchist movement will serve as a reminder in this regard, that neoliberal and capitalist attitudes toward property are incompatible with a genuine concern for the welfare of others.

\section{3c. The Practicalities of a Stateless Society}

Having demonstrated that there are key philosophical principles shared between Kropotkin and Maximus when it comes to anarchist 'well-being' and Christian 'love', I present some of Kropotkin's practical suggestions that may be of use in Christian ethics. As a result of his dedication to human well-being, Kropotkin presented ideas for anarchist organising as an alternative to exploitative societal structures premised on inequity of power and wealth. Given the similarities that have been explored, I believe the methods for organising Kropotkin suggests, can be a place of inspiration to

${ }^{106}$ For the desert monastics this was also about a spiritual well-being, since such attachment to material possessions also distracted from attention to God. The rejection of worldly goods was a rejection of the wealth of the world, so that an ascetic might instead focus on spiritual wealth. Spiritual wealth was concerned with good spiritual practice, good spiritual relation with God, and good spiritual relation with human and non-human creation.

ro7 Which may entail the distribution of resources, or the means of production being in the hands of workers, but these things are important only in so far as they are part of an ethics that works toward human well-being.

${ }^{108}$ For example see the writings of Pelagius, I 5; Joachim of Fiore, 36; John Ball, 4I; Winstanley, I 28 in A. Bradstock \& C. Rowland (eds.) Radical Christian Writings: A Reader. (Oxford: Blackwell Publishers Ltd, 2002). 
Christian practical ethics as well. I believe that the ethical principles present in Byzantine ascetic Christian theology have much more in common with Kropotkin's ideas for a stateless society, than the exploitative structures of present-day states. Although the writings of Maximus, Gregory of Nyssa, Basil of Caesarea, and the desert fathers and mothers had a much more personal and introspective dimension, they fundamentally discuss the character and structure of personal relationships. When asking what it means to live in a community structured upon those personal loving relationships, I believe a good set of practical suggestions can be found in the works of Kropotkin, who at the end of the day, has a vision for human living that is very familiar to Christian ethics.

Kropotkin's vision is that life be led in communities that freely cooperate with one another, and that the freedom of each never be compromised or subjugated. Human relations must be based upon free agreement, he proposes. There must be "a society of equals" so that it becomes "an organism so constructed as to combine all the efforts for procuring the greatest sum possible of well-being for all, while full, free scope will be left for every individual initiative". ${ }^{\text {rog }}$ By nature of being a community built upon free relation,

this society will not be crystallised into certain unchangeable forms, but will continually modify its aspect, because it will be a living, continually evolving organism; no need of government will be felt, because free agreement and federation take its place in all those functions which governments consider as theirs at the present time, and because, the causes of conflict being reduced in number, those conflicts which may still arise can be submitted to arbitration. ${ }^{\text {I } 10}$

Community cannot be static because relation is not static. The needs of one human differ from another, and a society must have the flexibility to serve the needs of each as well as the needs of many. Kropotkin suggests a society built on federated communities, where people might regulate their own local communities,

109 Kropotkin, Memoirs, 398.

по Kropotkin, Memoirs, 399. 
so that "society will be composed of a multitude of associations, federated for all the purposes which require federation" and "all these will combine directly, by means of free agreements between them, just as the railway companies or the postal departments of different countries cooperate now, without having a central railway or postal government, - even though the former are actuated

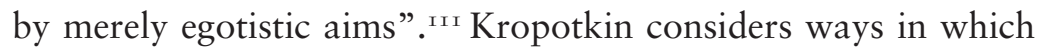
industry, agriculture, and social organisation might realistically exist without reliance on the perpetuation of poverty or the oppression of fellow humans. The kind of critical thinking he encouraged questioned the necessity of any system built upon the subjugation of another being. His ideas therefore comprise practical ways in which people might cooperate with one another without exercising coercive power. ${ }^{\mathrm{II} 2}$ The political critique Kropotkin proposes is that cooperative community and mutual aid are a better root of human society than accumulation of wealth for the self and the few and coercive defence of private property. Since humans can mutually co-operate, Kropotkin's ethics ends up saying, humans should mutually co-operate.

Kropotkin's theoretical ideas for the structure of an anarchist society are inseparable from his concern for the human condition. His ethics does not shy away from radical socio-political and economic conclusions and is demonstrative of how an ethics of human relation must resolve itself into a new vision for human society. We can see this for example within his work, Fields, Factories and Workshops, which was first collected into a book in I 899. ${ }^{\text {II3 }}$ In this work, Kropotkin outlines four aspects of his anarchist vision. The first is the decentralisation of industries which allows us "To return to a state of affairs where corn is grown, and manufactured goods are fabricated, for the use of those very people who grow and produce them," so that "Each region will become its own producer and its own consumer of agricultural produce". ${ }^{\mathrm{II} 4}$ The second looks at the possibilities of agriculture, and how the market garden might be put to good use. The main

\footnotetext{
iI Kropotkin, Memoirs, 398-9.

I2 Kropotkin, Mutual, 223.

I13 Ward, introduction to Kropotkin, Fields, iv.

${ }^{14} 4$ Kropotkin, Fields, 40.
} 
point of this section is to illustrate that it is always within our means to produce food locally to feed a population. ${ }^{115}$ On this, he says, "The obstacles against it are not in the imperfection of the agricultural art, or in the infertility of the soil, or in climate. They are in our institutions, in our inheritances and survivals from the past - in the 'Ghosts' which oppress us". ${ }^{\text {II }}$ His point is that our cultural, traditional, political and economic practices are tied to our current institutions and prevent us from attempting to create local, self-sustaining economies and agriculture. In his third section, Kropotkin discusses the necessity of "producing for the producers themselves" and also the healthy need for all people to be involved to some degree in manual outdoor labour. ${ }^{117}$ On a similar theme, the last area Kropotkin covers is education: “'Through the eyes and the hand to the brain' - this is the true principle of economy of time in teaching." ${ }_{\text {II } 8}$ Kropotkin is keen to emphasise that understanding of the theoretical comes through the practical, and that this is true in school-learning, but also in the societies that we construct. We cannot understand labour unless we labour. ${ }^{119}$ In Fields, Factories and Workshops, Kropotkin demonstrates the need for our economic and political decisions never to occur in isolation from our social and ethical thought. The two belong to one another and inform each other and are built on one another.

Of particular note in terms of compatibility with Maximus' ethical vision, is Kropotkin's concern that "society will not be crystallised into certain unchangeable forms" ${ }_{220}$ so as to best reflect and grow with the needs of its citizens. The understanding that, in Ward's words, "there is no final struggle" ${ }^{22}$ but that our relationships - personal and communal - must be continually worked at, is one that recognises that we are demanding the impossible.

${ }^{115}$ Kropotkin, Fields, I03; This is still the case today with responsible changes to land use and diet, cf. S. Fairlie 'Can Britain Feed Itself' The Land 4 Winter (2007-8): I 8-26.

${ }^{116}$ Kropotkin, Fields, I06.

${ }_{117}$ Kropotkin, Fields, I 58.

I18 Kropotkin, Fields, I75.

I19 Kropotkin, Fields, I 86.

I20 Kropotkin, Memoirs, 399.

I21 Ward, Anarchy, 37. 
In always setting our sights higher, we keep our communities from stagnating into what is easy, and require ourselves to always seek better ways to live in compassion with those around us. One of the principle metaphysical differences between Maximus and Kropotkin, is that for Maximus, ultimately our life on earth is directed towards God, whilst Kropotkin's ethics is thoroughly rooted in human aims and ends. Although this is a key difference between these two thinkers, practically speaking, it could be another place of comparative similarity. For Maximus there is no completion point in which our ethical responsibilities are done. Ethics is human choice to seek love and knowledge i.e. to seek God. There is always more to learn about God and more ways to grow in love. Even then in theosis, the end hope of all creation for final rest in God, we still anticipate ever-moving rest, ${ }^{\mathrm{I} 22}$ a rest in which relationship continues to ever deepen. In our lives here and now, we can thus also see for Maximus a dedication to the idea that human relationship rooted in love, is a relationship that must continually grow and recognise its own shortcomings. As a practical ethical principle, the idea that there is not one set end for human society, but that we must continually and consciously seek to revise our communities into places where particular and communal well-being can flourish, is one both startlingly anarchist and Byzantine in character.

\section{Conclusion}

Thus we can see that there is a potential compatibility between the ethical vision proposed by Maximus the Confessor and the practical means of coexistence proposed by Kropotkin. While Maximus' thought is firmly rooted within a Christian cosmos, and sees both the origin and end of things as being in God, the ethics necessitated by his theology is very close to a number of anarchist considerations. The love of Christ explored by Maximus is one that upturns a status quo that places value on wealth, power, and coercion. In exploring the spiritual significance of rooting our actions in love, Maximus presents us not just with a vision for

${ }^{\text {I22 }}$ Maximus, Ad Thal. 59 CCSG22 line I3 I. 
$7^{\text {th }}$ century ascetic living, but also an ethics that identifies care for fellow creatures as the root of economic and political relation. In likewise identifying Kropotkin's ideas as politico-economic theories that stem from social concerns, we can see that common care for the well-being of others necessarily challenges us to rethink the structures of the societies and institutions in which we live. The divergence in philosophical frameworks between Maximus and Kropotkin does not mean there cannot be agreement as to what good human living looks like, and consequently a shared vision of how to create a better human society.

In the process of describing the utility of anarchist theory to Christians who wish to make use of Maximus' thought, my hope is that this chapter will make some contribution towards selfcriticism within the Christian faith, and a wider interest in the lessons that can be learned from others similarly dedicated to the well-being of the marginalised and down-trodden. I hope it has also become clear to those of us who identify as anarchists, that many of the political and historical problems associated with the church, are not expressive of all theology underlying the Christian faith. This is a theology that is not just limited to the faith of the apostolic era (as implied by Kropotkin), ${ }^{\mathrm{I} 23}$ nor to the Byzantine era, since it is very much alive today in theological study and also in different denominations of the church.

So long as giving to each according to their need is paramount to human activity, which I think both Maximus' concept of love and Kropotkin's dedication to well-being both affirm, there is much hope to be had for united practical endeavour. At the very least, there is certainly a lot in the practical ideas put forward by anarchists like Kropotkin, that can be explored further in Christian ethics as an alternative to complicity in societal structures that have no place for the love of Christ. Christ's love challenges the foundations of nationalisms, racisms, classisms, sexisms, and any other hatreds and division. It is this specific character of love that Maximus suggests is fundamental to a theological cosmology that asks who we are as humans and where we are going. This theology sits in firm contradiction to societies and ideologies built on

${ }^{123}$ Kropotkin, Ethics, I 20-I. 
the glorification of wealth and power, so at the very least, it seems important to explore the radical alternatives set forward by thinkers like Peter Kropotkin.

\section{Abbreviations}

Ad Thal. Quaestiones ad Thalassium (Questions Addressed to Thalassius)

Amb. Ambiguorum liber de variis difficilibus locis Sanctorum Dionysii Areopagitae et Gregorii Theologii (Difficulties found in Dionysios the Areopagite and Gregory the Theologian)

De char. Centuriae de charitate (Centuries on Love)

Ep. $\quad$ Epistulae (Letters)

Myst. Mystagogia (Mystagogy)

Or. Dom. Orationis Dominicae expositio (Commentary on the Lord's Prayer)

Th.oec. Capita theologica et oeconomica (Chapters on Theology and Economy)

CCSG Corpus Christianorum. Series Graeca

PG Patrologia Graeca

\section{References}

\section{Greek Sources}

Maximus, 'Ad Thalassium 2' in Corpus Christianorum. Series Graeca 7, Turnhout: Brepols, I980.

Maximus, 'Ad Thalassium 59' in Corpus Christianorum. Series Graeca 22, Turnhout: Brepols, I980.

Maximus, 'Ambiguua I-22' in On Difficulties in the Church Fathers: The Ambiguua Vol I. N. Constas, (ed.) London: Harvard University Press, 20I4.

Maximus, 'Ambiguua 23-7I' in On Difficulties in the Church Fathers: The Ambiguua Vol II. N. Constas, (ed.) London: Harvard University Press, 20I4.

Maximus, 'Capita theologica et oeconomica' in Migne, J. Patrologia Graeca (vol. 90). Paris, (I865), I084-I I73. 
Maximus, 'Centuriae de charitate' in Patrologia Graeca (vol. 90). Migne, J. (ed.). Paris, ( I 865), 959-I080.

Maximus, 'Epistula I2' in Patrologia Graeca (vol. 9I). Migne, J. (ed.). Paris, (I 865), 460-509.

Maximus, 'Mystagogia' in Massimo Confessore. La mistagogia ed altri scritti. Cantarella, R. (ed.). Florence: Testi Cristiani, (I93I), I22-2I 4 .

Maximus, 'Orationis Dominicae expositio' in Patrologia Graeca (vol. 90). Migne, J. (ed.). Paris, (I865), 87 I-9 IO.

\section{English Sources}

Allen, P. "The Life and Times of Maximus the Confessor", The Oxford Handbook of Maximus the Confessor. Allen, P. \& Neil, B. (eds.), Oxford: Oxford University Press, 201 5.

Basil of Caesarea, On Social Justice. C.P. Schroeder (trans.) New York: St Vladimir's Seminary Press, 2009.

Berthold, G. Maximus Confessor: Selected Writings. London: SPCK, I985.

Blowers, P. \& Wilken, R. On the Cosmic Mystery of Jesus Christ. New York: St Vladimir's Seminary Press, 2003.

Bradshaw, D. 'The Logoi of Beings in Greek Patristic Thought' in Toward an Ecology of Transfiguration: Orthodox Christian Perspectives on Environment, Nature and Creation. Chryssavgis, J. \& Foltz, B. (eds.), 9-22. Fordham: Fordham University Press, 20I3.

Bradstock, A. \& Rowland, C. (eds.) Radical Christian Writings: A Reader. (Oxford: Blackwell Publishers Ltd, 2002).

Brenna, C. 'Orthodox Cosmology and Modern Rights Theories: A Proposal for Political Dialogue and Change'. Paper presented at the Orthodox Theological Society of America 2012 Annual Meeting, Yonkers, New York, September 20-22, 20I 2. Available on request.

Brown Dewhurst, E. Revolution in the Microcosm: Love and Virtue in the Cosmological Ethics of St Maximus the Confessor. PhD diss., Durham University, 2018. (Available online: http:// 
etheses.dur.ac.uk/I 2376/I/Brown_Dewhurst-_Revolution_in_the_ Microcosm.pdf?DDD $32+)$

Bordeianu, R. 'Maximus and Ecology: The Relevance of Maximus the Confessor's Theology of Creation for the Present Ecological Crisis'. The Downside Review, I27 (2009), I03-I 26.

Chomsky, N. Chomsky on Anarchism. Pateman, B. (ed.) Edinburgh: AK Press, 2005.

Chryssavgis, J. \& Foltz, B. (eds.), Toward an Ecology of Transfiguration: Orthodox Christian Perspectives on Environment, Nature and Creation. Fordham: Fordham University Press, 2013.

Cvetković, V. 'Maximus the Confessor's Geometrical Analogies applied to the Relationship between Christ and Creation' in Pavlov, P., Tanev S. \& Dragas, G. (eds), Orthodox Theology and the Sciences. Columbia: Newrome Press, 2013.

Fairlie, S. 'Can Britain Feed Itself' The Land 4 Winter (2007-8), I 8-26.

Grdzelidze, T. 'Creation and Ecology: How Does the Orthodox Church Respond to Ecological Problems?' The Ecumenical Review. 54, 3 (2002), 2I I-2 I 8.

Gregory of Nyssa, 'On the Soul and the Resurrection' in Gregory of Nyssa: Dogmatic Treatises Moore, W. \& Wilson, H.A. (trans.) New York: Christian Literature Publishing Co. I 892.

Harvey, D. A Brief History of Neoliberalism. Oxford: Oxford University Press 2007.

Louth, A. 'Man and Cosmos in St Maximus the Confessor' in Toward an Ecology of Transfiguration: Orthodox Christian Perspectives on Environment, Nature and Creation. Chryssavgis, J. \& Foltz, B. (eds.), 59-7I. Fordham: Fordham University Press, 20I3.

Louth, A. Maximus the Confessor. London: Routledge, I996.

Keselopoulos, A. 'The Prophetic Charisma in Pastoral Theology: Asceticism, Fasting, and the Ecological Crisis' in Toward an Ecology of Transfiguration: Orthodox Christian Perspectives on Environment, Nature and Creation. Chryssavgis, J. \& Foltz, B.(eds.), 356-364. Fordham: Fordham University Press, 20I3. 
Kropotkin, P. The Conquest of Bread. Milton Keynes: Dodo Press, I892.

Kropotkin, P. Ethics: Origin and Development. Québec: Black Rose Books Ltd., I992 (I922 I ${ }^{\text {st }}$ ed.).

Kropotkin, P. Fields, Factories and Workshops Tomorrow. London: Freedom Press, ( I ${ }^{\text {st }}$ ed. I 898) I998.

Kropotkin, P. Memoirs of a Revolutionist. New York: Dover Publications, I97I (I899 ( ( ${ }^{\text {st }}$ ed.)).

Kropotkin, P. Mutual Aid: A Factor of Evolution. Boston: Extending Horizons Books, I902.

Marshall, P. Demanding the Impossible: A History of Anarchism. London: Harper Perennial, 1992.

Mitralexis, S. 'Rethinking the Problem of Sexual Difference in Ambiguum 4I' Analogia: The Pemptousia Journal for Theological Studies 2:I 20I7.

Munteanu, D. 'Cosmic Liturgy: The Theological Dignity of Creation as a Basis of an Orthodox Ecotheology'. International Journal of Public Theology. 4, 3 (2010), 332-44.

No Borders, 'A No Borders Manifesto': http://noborders.org.uk/ node/47 (accessed 20.03.I4).

Papanikolaou, A. The Mystical As Political: Democracy and NonRadical Orthodoxy. Notre Dame: University of Notre Dame Press, 2012.

Popa, G. 'Theology and Ecology: Hermeneutical Insights for Christian Eco-Theology'. Journal for Interdisciplinary Research on Religion and Science. 2 (2008), 97-I 28.

Proudhon, P. 'Property is Theft' in No Gods, No Masters. D. Guerin (ed.), Edinburgh: AK Press, 1998.

Sherwood, P. St Maximus the Confessor: The Ascetic Life \& The Four Centuries on Charity. London: Longmans, Green and Co., I 955.

Theokritoff, E. Living in God's Creation: Orthodox Perspectives on Ecology. New York: St Vladimir's Seminary Press, 2009.

Tollefsen, T. The Christocentric Cosmology of St Maximus the Confessor. Oxford: Oxford University Press, 2008. 
Törönen, M. Union and Distinction in the Thought of St Maximus the Confessor. Oxford: Oxford University Press, 2007.

Von Balthasar, H. Cosmic Liturgy: The Universe According to Maximus the Confessor. Daley, B. (trans.) San Francisco: Ignatius Press, (I ${ }^{\text {st }}$ ed. I946) I988.

Ward, C. Anarchy in Action. London: Freedom Press, ( $\mathrm{I}^{\text {st }}$ ed.I973) 2008.

Ward, C. 'Introduction' in Kropotkin, P. Fields, Factories and Workshops Tomorrow. (London: Freedom Press, ( ( ${ }^{\text {st }}$ ed. I 898) I998).

Ware, K. 'Through Creation to the Creator' in Toward an Ecology of Transfiguration: Orthodox Christian Perspectives on Environment, Nature and Creation. Chryssavgis, J. \& Foltz, B. (eds.), 86-105. Fordham: Fordham University Press, 2013.

Wortley, J. (ed. \& trans.) The Anonymous Sayings of the Desert Fathers: A Select Edition and Complete English Translation. 'The Quarrel', N.352/I7.26

Zelensky, E. 'Nature as Living Icon: Ecological Ethos of Eastern Orthodoxy'. Religions: Vol. Environment, I I (2012), I67-I79. 